\title{
Mild progressive multifocal leukoencephalopathy after switching from natalizumab to ocrelizumab
}

Alyssa A. Toorop, MD, Zoë Y.G. van Lierop, MD, Eva E.M. Strijbis, MD, PhD, Charlotte E. Teunissen, PhD, Axel Petzold, MD, PhD, Mike P. Wattjes, MD, PhD, Frederik Barkhof, MD, PhD, Brigit A. de Jong, MD, PhD, Zoé L.E. van Kempen, MD, PhD, and Joep Killestein, MD, PhD

Neurol Neuroimmunol Neuroinflamm 2021;8:e904. doi:10.1212/NXI.0000000000000904

\author{
Correspondence \\ Dr. Toorop \\ a.toorop@amsterdamumc.nl
}

\begin{abstract}
\section{Objective}

To describe the disease course of carryover progressive multifocal leukoencephalopathy (PML) after switching from natalizumab to ocrelizumab in 2 patients with relapsing-remitting MS.
\end{abstract}

\section{Methods}

Two case reports with 1 year of follow-up and retrospective longitudinal measurements of serum neurofilament light (NfL) levels and B-cells.

\section{Results}

PML was diagnosed 78 days (case 1) and 97 days (case 2) after discontinuation of natalizumab. Both patients developed mild immune reconstitution inflammatory syndrome (IRIS) despite B-cell depletion caused by ocrelizumab. NfL levels increased in both patients during PML-IRIS. PML-IRIS lesions stabilized after treatment with mefloquine and mirtazapine, followed by methylprednisolone, and both patients continued therapy with ocrelizumab when B-cells started to repopulate.

\section{Conclusions}

The clinical course of carryover PML was mild in both patients, suggesting that B-cell depletion possibly did not aggravate PML-IRIS in these 2 patients.

\footnotetext{
From the Department of Neurology (A.A.T., Z.Y.G.L., E.E.M.S., B.A.J., Z.L.E.K., J.K.), Amsterdam University Medical Centers, Vrije Universiteit Amsterdam, Amsterdam Neuroscience, MS Center Amsterdam; Department of Clinical Chemistry (C.E.T.), Neurochemistry Laboratory and Biobank, Amsterdam Neuroscience, Amsterdam University Medical Centers, Vrije Universiteit Amsterdam; Department of Ophthalmology (A.P.), Neuro-ophthalmology Expertise Center, Amsterdam Neuroscience, Amsterdam University Medical Centers, Vrije Universiteit Amsterdam, Amsterdam, the Netherlands; Department of Diagnostic and Interventional Neuroradiology (M.P.W.), Hanover Medical School, Hanover, Germany; Department of Radiology and Nuclear Medicine (M.P.W., F.B.), Amsterdam University Medical Centers, Vrije Universiteit Amsterdam, Amsterdam Neuroscience, MS Center Amsterdam, the Netherlands; Department of Neuroinflammation (F.B.), Queen Square MS Centre, UCL Institute of Neurology, Faculty of Brain Sciences, University College London; and National Institute for Health Research (NIHR) University College London Hospitals (UCLH) Biomedical Research Centre (F.B.), London, United Kingdom.

Go to Neurology.org/NN for full disclosures. Funding information is provided at the end of the article.

The Article Processing Charge was funded by the authors.

Informed consent: Both patients provided oral and written informed consent for publishing of this article.
}

This is an open access article distributed under the terms of the Creative Commons Attribution-NonCommercial-NoDerivatives License 4.0 (CC BY-NC-ND), which permits downloading and sharing the work provided it is properly cited. The work cannot be changed in any way or used commercially without permission from the journal. 


\section{Glossary}

EDSS $=$ expanded disability status scale; EID $=$ extended interval dosing; IRIS = immune reconstitution inflammatory syndrome; IVMP = IV methylprednisolone; JCV = John-Cunningham virus; NfL = neurofilament light; PML = progressive multifocal leukoencephalopathy; RRMS = relapsing-remitting MS; sNfL = serum NfL.

Natalizumab is an effective drug approved for the treatment of relapsing-remitting MS (RRMS). A rare but dangerous complication is progressive multifocal leukoencephalopathy (PML), an opportunistic infection of the brain caused by the John-Cunningham virus (JCV). After PML diagnosis, discontinuation of natalizumab often leads to immune reconstitution inflammatory syndrome (IRIS). ${ }^{1}$

Ocrelizumab is another effective disease-modifying therapy in MS. Nine confirmed cases of PML have been reported in patients using ocrelizumab, although not yet published (Clifford et al. ECTRIMS 2020; Roche data on file 2020). In 8 cases, patients previously used natalizumab or fingolimod, likely causing PML. This phenomenon has been described as carryover PML. ${ }^{2}$

Neurofilament light (NfL) is a promising biomarker of neuronal damage and could potentially support early radiologic findings of PML. ${ }^{3,4}$ We report 2 cases of carryover PML-IRIS after switching from natalizumab to ocrelizumab with a relatively mild clinical disease course in whom longitudinal serum NfL ( $\mathrm{sNfL}$ ) was measured in retrospect.

\section{Data availability}

Anonymized data will be shared by request from any qualified investigator.

\section{Standard protocol approvals, registrations and patient consents}

Both patients provided informed consent for publishing of this article.

\section{Case 1}

A 34-year-old man with RRMS started treatment with natalizumab in 2012. JCV serostatus was positive (index 2.22-3.23 between 2012 and 2018) as measured by the STRATIFY-2 test (Unilabs, Copenhagen, Denmark). The patient wished to continue treatment despite PML risk. Consequently, every 3 months, MRI brain scans were performed as per local

Figure 1 Magnetic resonance images demonstrating the disease course of PML-IRIS of case 1

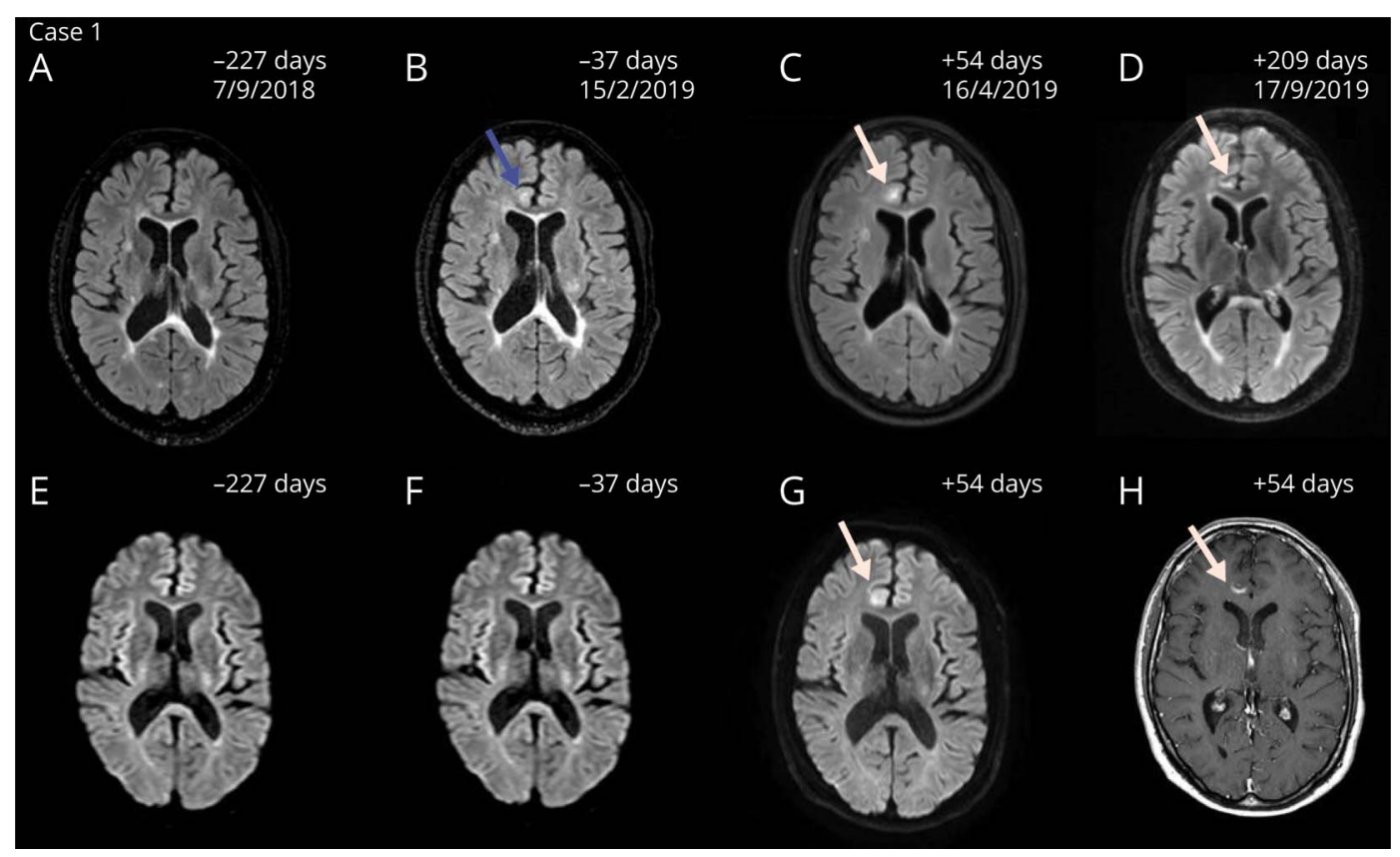

Axial FLAIR (A-D), diffusion-weighted (E-G), and contrast-enhanced T1-weighted (H) magnetic resonance images of PML with IRIS of case 1. In late March 2019, a fast-growing juxtacortical white matter lesion in the right frontal lobe suspect for PML was detected. Follow-up scans showed progression of enhancement suspect for PML-IRIS (C, D, G, H). The amount of days indicates the time from the first infusion with ocrelizumab. Natalizumab was discontinued in January 2019, and PML was diagnosed after 78 days. Blue arrow indicates subtle signs suggestive of PML in retrospect before diagnosis (B). White arrows indicate the lesions suggestive of PML-IRIS. FLAIR = fluid-attenuated inversion recovery; IRIS = immune reconstitution inflammatory syndrome; PML = progressive multifocal leukoencephalopathy. 
A. Case 1

60 T

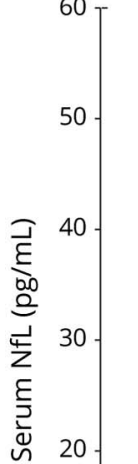

Serum NfL

- B-cells

IVMP

Therapy PML$$
10
$$
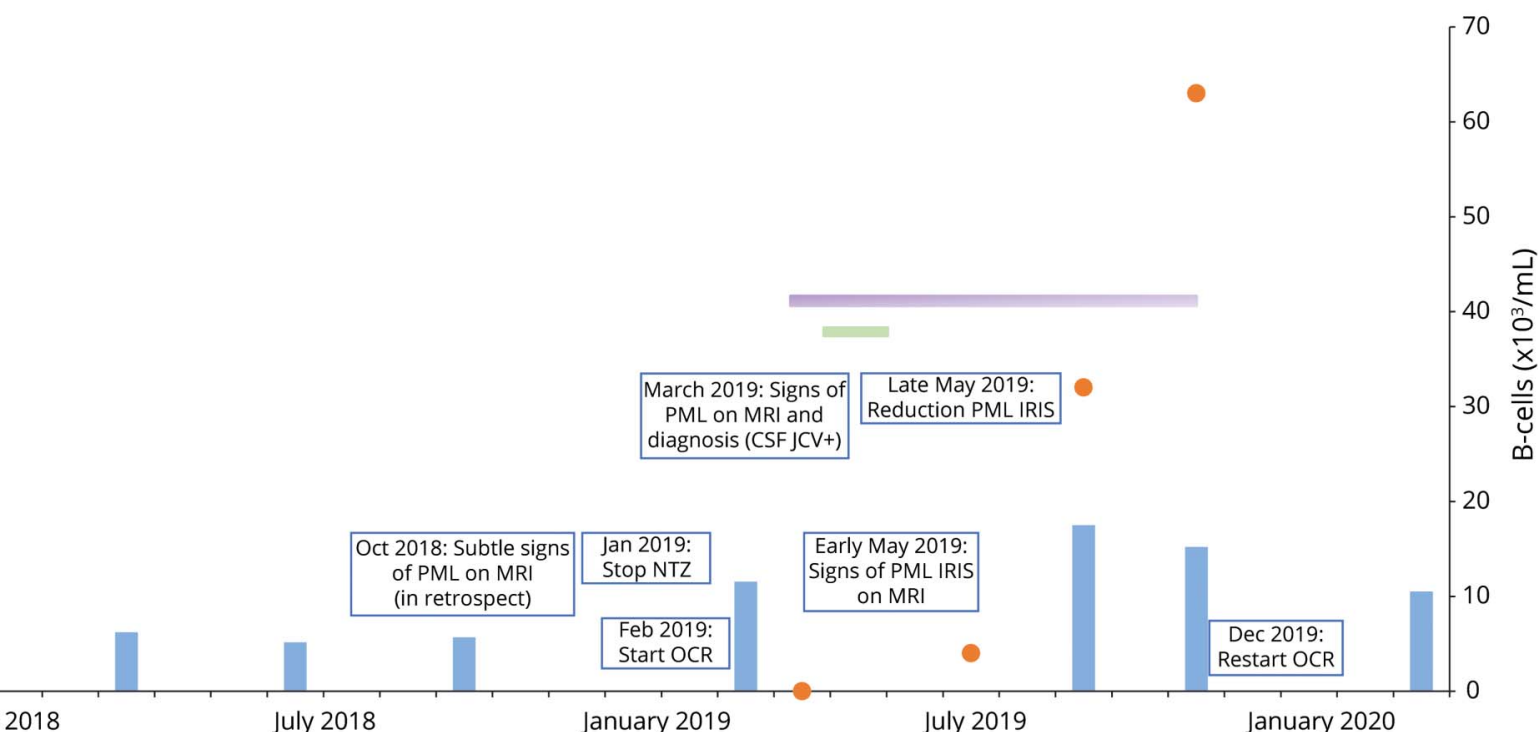

B. Case 2
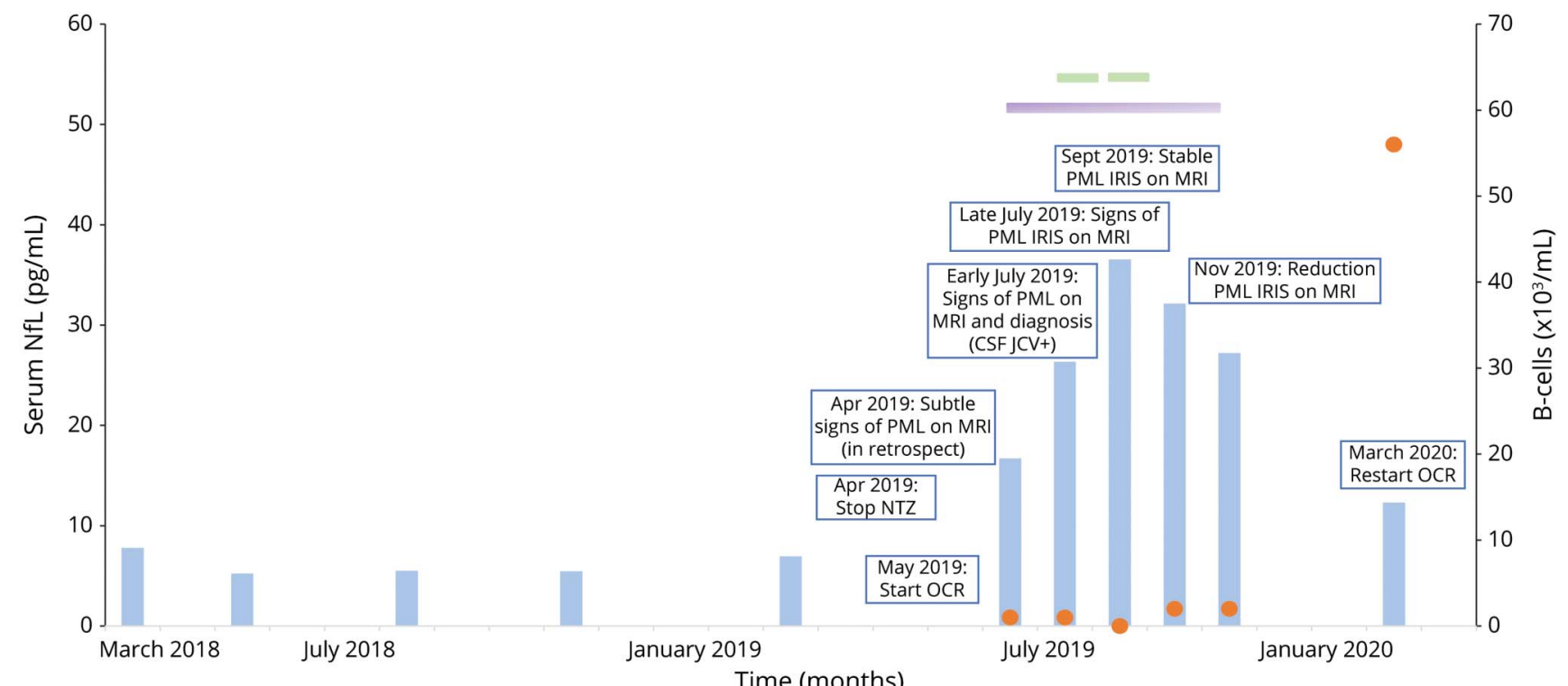

Longitudinal serum NfL levels (Left Y-axis) and B-cells (Right Y-axis) over time (X-axis; months) during PML-IRIS for case 1 (A) and case 2 (B). No immunosuppressant therapy was used before treatment with natalizumab in both cases. $\mathrm{NfL}=$ neurofilament light (case 1 reference range $1-15 \mathrm{pg} / \mathrm{mL}$; case 2 reference range $2-18 \mathrm{pg} / \mathrm{mL}$ ); Therapy for PML consists of mefloquine and mirtazapine. CSF NfL levels in case 1 were 396 pg/mL before PML diagnosis, 844 pg/ $\mathrm{mL}$ after diagnosis, and $1,212 \mathrm{pg} / \mathrm{mL}$ after recovery. CSF NfL levels in case 2 were $211 \mathrm{pg} / \mathrm{mL}$ before PML diagnosis and $466 \mathrm{pg} / \mathrm{mL}$ after diagnosis. IRIS = immune reconstitution inflammatory syndrome; IVMP = IV methylprednisolone; NTZ = natalizumab; OCR = ocrelizumab; PML = progressive multifocal leukoencephalopathy.

pharmacovigilance scan protocol. ${ }^{5}$ The follow-up showed no disease activity under natalizumab treatment. In January 2019, because of the patient's desire for a treatment switch to ocrelizumab, natalizumab was discontinued. Per local pharmacovigilance scan protocol to exclude PML before ocrelizumab, 2 MRI brain scans showed no new or enlarging T2 lesions and CSF was negative for JCV DNA with CSF NfL levels of 396 $\mathrm{pg} / \mathrm{mL}$. The expanded disability status scale (EDSS) score was 4.0. The patient received $300 \mathrm{mg}$ of ocrelizumab 43 days after the last natalizumab infusion. A third MRI was performed per local pharmacovigilance protocol before the second $300 \mathrm{mg}$ ocrelizumab infusion. A white matter lesion suspect for PML was detected (figure 1). No lesions suspect for MS disease activity were present. In retrospect, subtle signs suggestive of PML were 


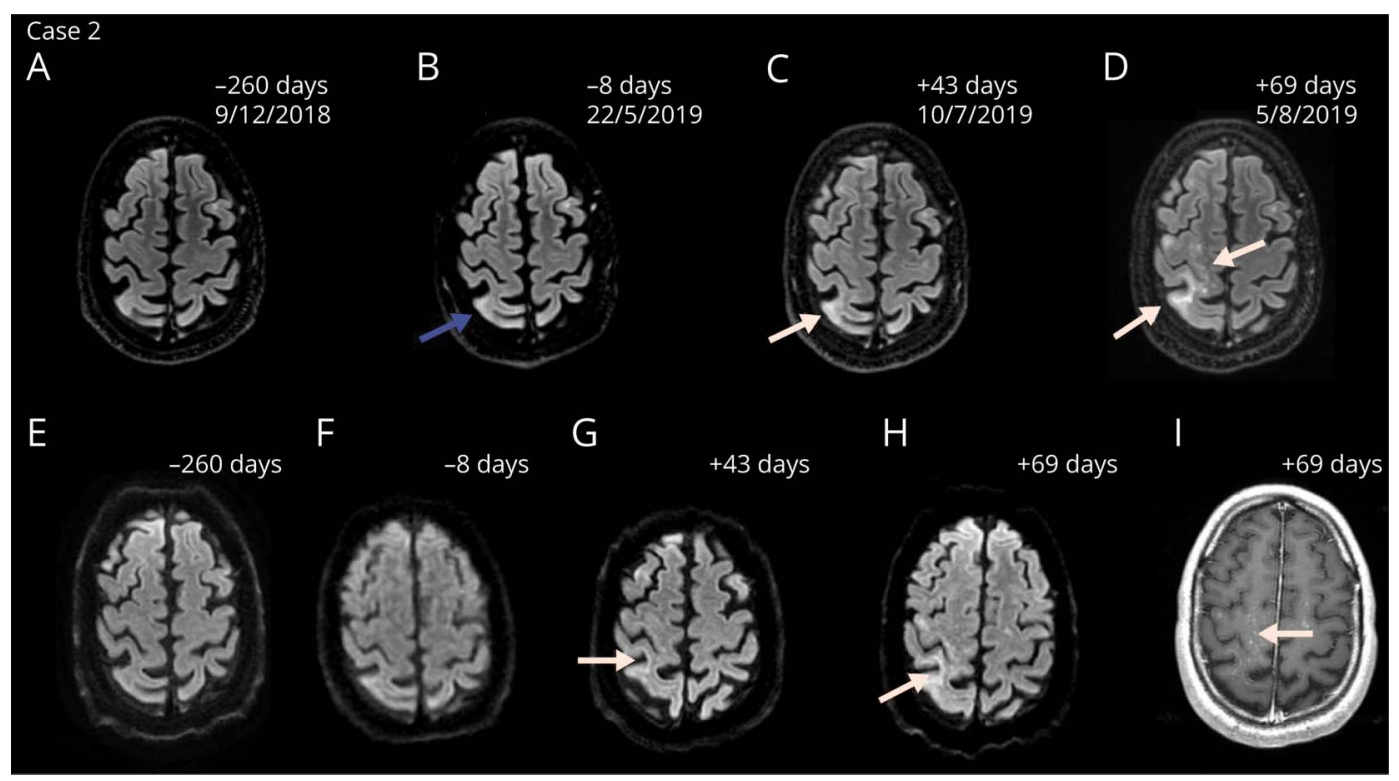

Axial FLAIR (A-D), diffusion-weighted (E-H) and contrast-enhanced T1-weighted (I) magnetic resonance images of PML with IRIS of case 2. In July 2019, new focal areas with elevated signal on the diffusion weighted imaging setting in the right pre- and postcentral gyrus and gyrus supramarginalis were detected (C and $G)$. Follow-up scans showed multiple foci of elevated signal suspect for PML-IRIS (D, $H, I)$. The amount of days indicates the time from the first infusion with ocrelizumab. Natalizumab was discontinued in April 2019 and PML was diagnosed after 97 days. Blue arrow indicates subtle signs suggestive of PML in retrospect before diagnosis $(B)$. White arrows indicate the lesions suggestive of PML-IRIS. FLAIR = fluid-attenuated inversion recovery; IRIS = immune reconstitution inflammatory syndrome; $\mathrm{PML}=$ progressive multifocal leukoencephalopathy

already present on MRI in October 2018 under natalizumab treatment. CSF was positive for JCV DNA (11.0 copies $/ \mathrm{mL}$ ). CSF NfL levels increased to $844 \mathrm{pg} / \mathrm{mL}$, and sNfL levels were $9.9 \mathrm{pg} / \mathrm{mL}$ (figure $2 \mathrm{~A}$ ). Based on limited evidence, the patient started mefloquine $250 \mathrm{mg}$ for 3 days, continued at a dose of $250 \mathrm{mg}$ weekly, and mirtazapine $30 \mathrm{mg}$ daily. ${ }^{6} \mathrm{MRI}$ brain scans with gadolinium showed progression of enhancement suspect for PML-IRIS. The patient received $1 \mathrm{~g}$ IV methylprednisolone (IVMP) for 3 days. Over the next 2 months, MRI scans showed a decrease of the inflammatory component of PML-IRIS and treatment for PML was discontinued. CSF was negative for JCV DNA. The neurologist felt comfortable to continue treatment with $300 \mathrm{mg}$ of ocrelizumab after the first signs of B-cell repopulation. The patient reported no clinical symptoms during the disease course of PML-IRIS with a stable EDSS score of 4.0.

\section{Case 2}

A 37-year-old man with RRMS started treatment with natalizumab in 2009. JCV serostatus was positive (index 0.37-0.84 between 2014 and 2019). The patient wished to continue natalizumab treatment; consequently, every 3 months, MRI brain scans were performed. ${ }^{5}$ Regular follow-up showed no disease activity under natalizumab treatment. In January 2017, the patient switched to personalized extended interval dosing (EID) based on trough concentrations (6 week interval). In April 2019, because of the patient's desire for treatment switch, natalizumab was discontinued. Two MRI brain scans showed no new or enlarging T2 lesions, and CSF was negative for JCV
DNA with CSF NfL levels of $211 \mathrm{pg} / \mathrm{mL}$. The EDSS score was 2.5. The patient received $300 \mathrm{mg}$ of ocrelizumab 55 days after the last natalizumab infusion. A third MRI scan showed new focal areas with elevated signal on the diffusion-weighted imaging setting (figure 3). No lesions suspect for MS disease activity were present. In retrospect, subtle signs suggestive of PML were already present on MRI in May 2019 under natalizumab treatment. CSF was positive for JCV DNA (copy number not quantified). CSF NfL levels increased to $466 \mathrm{pg} /$ $\mathrm{mL}$, and sNfL levels were $16.7 \mathrm{pg} / \mathrm{mL}$ (figure $2 \mathrm{~B}$ ). The patient started mefloquine $250 \mathrm{mg}$ for 3 days, continued at a dose of $250 \mathrm{mg}$ weekly, and mirtazapine $60 \mathrm{mg}$ daily. ${ }^{6}$ Two weeks later, an MRI with gadolinium showed multiple foci of elevated signal suspect for PML-IRIS. By then, the patient became symptomatic with a mild left upper limb paresis. There was worsening of his gait because of instability of the left leg and new numbness of the right arm. The patient received $1 \mathrm{~g}$ IVMP twice, and the progression of clinical symptoms and lesions on MRI stabilized. Treatment for PML was discontinued in October 2019. Clinical symptoms improved, and the neurologist felt comfortable to continue treatment with $300 \mathrm{mg}$ of ocrelizumab after the first signs of B-cell repopulation. The patient reported only mild clinical symptoms during the disease course of PML-IRIS with an EDSS score of 2.5 after recovery.

\section{Discussion}

We report 2 patients with RRMS with a relatively mild disease course of carryover PML after switching from natalizumab to 
ocrelizumab. Interestingly, both patients developed IRIS despite complete B-cell depletion for several months after a single infusion of $300 \mathrm{mg}$ ocrelizumab. One patient developed PML despite EID of natalizumab. PML is described in patients on EID, implicating EID does not obliterate the risk of PML. However, a recent case series suggests a possible less severe disease course of PML in 4 patients on EID. ${ }^{7}$ Furthermore, 7 confirmed cases of carryover PML in patients with MS switching from natalizumab to ocrelizumab have been reported (Clifford et al. ECTRIMS 2020; Roche data on file 2020). Although not described in detail, 6 cases were nonfatal. In a previous case report in a patient with MS, complete B-cell depletion by rituximab did not aggravate PML and did not prevent development of IRIS. ${ }^{8}$ A histologic study showed that IRIS is predominantly initiated by CD8+ $\mathrm{T}$ cells in natalizumab-associated PML. ${ }^{9}$ However, high numbers of B-cells were present in lesions from patients with PML-IRIS, whereas no B-cells were present in lowinflammatory PML not related to natalizumab therapy. Because ocrelizumab caused total depletion of CD20+ B-cells in both patients, it might be possible that ocrelizumab allowed immune reconstitution by T-lymphocytes with reduction of the inflammatory component of IRIS by depletion of B-cells.

Both patients were asymptomatic at the time of PML diagnosis. Subtle radiologic signs of PML were initially missed despite an extensive protocol for radiologic detection of PML in our tertiary MS center. It has been previously described that MRI diagnosis of PML remains difficult because of heterogeneous lesions. ${ }^{10}$ We measured longitudinal sNfL levels before and during PML-IRIS in retrospect in one batch (figure 2). SNfL levels increased during development of PML-IRIS. After PML-IRIS stabilized, sNfL values started to decline. A recent cohort study showed elevation of $\mathrm{sNfL}$ at PML onset compared with sNfL levels before PML onset. ${ }^{3}$ Another study found a correlation between PML lesion volume and $\mathrm{sNfL} .{ }^{4} \mathrm{sNfL}$ was not elevated before radiologic diagnosis of PML. However, individual relative change of sNfL might be helpful to support early radiologic findings suspect for PML.

We present 2 cases of carryover PML-IRIS with a relatively mild disease course after switching from natalizumab to ocrelizumab. Depletion of B-cells by ocrelizumab possibly contributed to reduction of the inflammatory component of IRIS in these 2 patients.

\section{Study funding}

No targeted funding reported.

\section{Disclosure}

C.E. Teunissen has served on advisory boards for Roche, has received nonfinancial support in the form of research consumables from $\mathrm{ADx}$ NeuroSciences and Euroimmun, and has performed contract research or received grants from Probiodrug, Biogen, Esai, Toyama, Janssen Prevention Center, Boehringer, Axon Neuroscience, EIP Pharma, PeopleBio, and
Roche. M.P. Wattjes has received consultancy or speaking fees from Biogen, Novartis, Roche, Celgene, IXICO, Sanofi Genzyme, Bayer Healthcare, Biologix, Genilac, and Merck Serono. F. Barkhof is supported by the NIHR biomedical research centre at UCLH. J. Killestein has accepted speaker and consulting fees from Merck Serono, Biogen, Roche, Teva Pharmaceutical Industries, Genzyme, and Novartis. A.A. Toorop, Z.Y.G. van Lierop, E.E.M. Strijbis, A. Petzold, B.A. de Jong and Z.L.E. van Kempen report no disclosures. Go to Neurology.org/NN for full disclosures.

\section{Publication history}

Received by Neurology: Neuroimmunology \& Neuroinflammation June 17, 2020. Accepted in final form September 3, 2020.

Appendix Authors

\begin{tabular}{|c|c|c|}
\hline Name & Location & Contribution \\
\hline $\begin{array}{l}\text { Alyssa A. } \\
\text { Toorop, MD }\end{array}$ & $\begin{array}{l}\text { Department of Neurology, } \\
\text { Amsterdam University } \\
\text { Medical Centers, Vrije } \\
\text { Universiteit, Amsterdam }\end{array}$ & $\begin{array}{l}\text { Designed and } \\
\text { conceptualized study, } \\
\text { analyzed the data, and } \\
\text { drafted the manuscript } \\
\text { and figures for intellectual } \\
\text { content; }\end{array}$ \\
\hline
\end{tabular}

\begin{tabular}{lll}
\hline $\begin{array}{l}\text { Zoë Y.G. van } \\
\text { Lierop, MD }\end{array}$ & $\begin{array}{l}\text { Department of Neurology, } \\
\text { Amsterdam University } \\
\text { Medical Centers, Vrije } \\
\text { Universiteit, Amsterdam }\end{array}$ & $\begin{array}{l}\text { Interpreted the data and } \\
\text { revised the manuscript } \\
\text { for intellectual content. }\end{array}$ \\
\hline $\begin{array}{l}\text { Eva E.M. } \\
\text { Strijbis, MD, } \\
\text { PhD }\end{array}$ & $\begin{array}{l}\text { Department of Neurology, } \\
\text { Amsterdam University } \\
\text { Medical Centers, Vrije } \\
\text { Universiteit, Amsterdam }\end{array}$ & $\begin{array}{l}\text { Interpreted the data and } \\
\text { revised the manuscript } \\
\text { for intellectual content. }\end{array}$ \\
\end{tabular}

Charlotte E. Department of clinical Analyzed and interpreted
Teunissen, chemistry, Amsterdam the data and revised the

PhD University Medical Centers, manuscript for Vrije Universiteit, intellectual content. Amsterdam

\begin{tabular}{lll}
\hline Axel & Department of & Interpreted the data and \\
Petzold, & ophthalmology, & revised the manuscript \\
MD, PhD & Amsterdam University & for intellectual content. \\
& Medical Centers, Vrije & \\
& Universiteit, Amsterdam &
\end{tabular}

\begin{tabular}{lll}
\hline $\begin{array}{l}\text { Mike P. } \\
\text { Wattjes, }\end{array}$ & $\begin{array}{l}\text { Department of radiology and } \\
\text { nuclear medicine, }\end{array}$ & $\begin{array}{l}\text { Interpreted the data and } \\
\text { revised the manuscript } \\
\text { for intellectual content. }\end{array}$ \\
& $\begin{array}{l}\text { Amsterdam University } \\
\text { Medical Centers, Vrije }\end{array}$ & \\
& Universiteit, Amsterdam; & \\
& Department of diagnostic & \\
& and interventional & \\
& neuroradiology, Hanover & \\
& medical school, Germany & \\
\hline Frederik & Department of radiology and & Interpreted the data and \\
Barkhof, & nuclear medicine, & revised the manuscript \\
MD, PhD & Amsterdam University & for intellectual content. \\
& Medical Centers, Vrije & \\
& Universiteit, Amsterdam; & \\
& Department of & \\
& neuroinflammation, & \\
& University College, London &
\end{tabular}

\begin{tabular}{lll}
\hline Brigit A. de & Department of Neurology, & Interpreted the data and \\
Jong, MD, & Amsterdam University & revised the manuscript \\
PhD & Medical Centers, Vrije & for intellectual content. \\
& Universiteit Amsterdam &
\end{tabular}


Appendix (continued)

\begin{tabular}{|c|c|c|}
\hline Name & Location & Contribution \\
\hline $\begin{array}{l}\text { Zoé L.E. van } \\
\text { Kempen, } \\
\text { MD, PhD }\end{array}$ & $\begin{array}{l}\text { Department of Neurology, } \\
\text { Amsterdam University } \\
\text { Medical Centers, Vrije } \\
\text { Universiteit Amsterdam }\end{array}$ & $\begin{array}{l}\text { Designed and } \\
\text { conceptualized study, } \\
\text { analyzed the data, and } \\
\text { drafted the manuscript } \\
\text { for intellectual content }\end{array}$ \\
\hline $\begin{array}{l}\text { Joep } \\
\text { Killestein, } \\
\text { MD, PhD }\end{array}$ & $\begin{array}{l}\text { Department of Neurology, } \\
\text { Amsterdam University } \\
\text { Medical Centers, Vrije } \\
\text { Universiteit Amsterdam }\end{array}$ & $\begin{array}{l}\text { Designed and } \\
\text { conceptualized study, } \\
\text { analyzed the data, and } \\
\text { drafted the manuscript } \\
\text { for intellectual content }\end{array}$ \\
\hline
\end{tabular}

\section{References}

1. Kleinschmidt-DeMasters BK, Miravalle A, Schowinsky J, Corboy J, Vollmer T. Update on PML and PML-IRIS occurring in multiple sclerosis patients treated with natalizumab. J Neuropathol Exp Neurol 2012;71:604-617.

2. Giovannoni G, Marta M, Davis A, Turner B, Gnanapavan S, Schmierer K. Switching patients at high risk of PML from natalizumab to another disease-modifying therapy. Pract Neurol 2016;16:389-393.
3. Dalla Costa G, Martinelli V, Moiola L, et al. Serum neurofilaments increase at progressive multifocal leukoencephalopathy onset in natalizumab-treated multiple sclerosis patients. Ann Neurol 2019;85:606-610.

4. Loonstra FC, Verberk IMW, Wijburg MT, et al. Serum neurofilaments as candidate biomarkers of natalizumab associated progressive multifocal leukoencephalopathy. Ann Neurol 2019;86:322-324.

5. Wattjes MP, Barkhof F. Diagnosis of natalizumab-associated progressive multifocal leukoencephalopathy using MRI. Curr Opin Neurol 2014;27: 260-270.

6. Schröder A, Lee DH, Hellwig K, Lukas C, Linker RA, Gold R. Successful management of natalizumab-associated progressive multifocal leukoencephalopathy and immune reconstitution syndrome in a patient with multiple sclerosis. Arch Neurol 2010;67: 1391-1394.

7. Scarpazza C, De Rossi N, Tabiadon G, Turrini MV, Gerevini S, Capra R. Four cases of natalizumab-related PML: a less severe course in extended interval dosing? Neurol Sci 2019;40:2119-2124.

8. Asztely F, Gilland E, Wattjes MP, Lycke J. Rituximab treatment did not aggravate ongoing progressive multifocal leukoencephalopathy in a patient with multiple sclerosis. J Neurol Sci 2015;353:155-157.

9. Metz I, Radue EW, Oterino A, et al. Pathology of immune reconstitution inflammatory syndrome in multiple sclerosis with natalizumab-associated progressive multifocal leukoencephalopathy. Acta Neuropathol 2012;123: $235-245$.

10. Wattjes MP, Richert ND, Killestein J, et al. The chameleon of neuroinflammation: magnetic resonance imaging characteristics of natalizumabassociated progressive multifocal leukoencephalopathy. Mult Scler 2013;19: 1826-1840. 


\section{Neurology \\ Neuroimmunology \& Neuroinflammation}

\section{Mild progressive multifocal leukoencephalopathy after switching from natalizumab to ocrelizumab}

Alyssa A. Toorop, Zoë Y.G. van Lierop, Eva E.M. Strijbis, et al.

Neurol Neuroimmunol Neuroinflamm 2021;8;

DOI 10.1212/NXI.0000000000000904

This information is current as of October 13, 2020

Updated Information \&

Services

References

Subspecialty Collections

Permissions \& Licensing

Reprints including high resolution figures, can be found at:

http://nn.neurology.org/content/8/1/e904.full.html

This article cites 10 articles, 1 of which you can access for free at: http://nn.neurology.org/content/8/1/e904.full.html\#\#ref-list-1

This article, along with others on similar topics, appears in the following collection(s):

Multiple sclerosis

http://nn.neurology.org//cgi/collection/multiple_sclerosis

Information about reproducing this article in parts (figures,tables) or in its entirety can be found online at:

http://nn.neurology.org/misc/about.xhtml\#permissions

Information about ordering reprints can be found online: http://nn.neurology.org/misc/addir.xhtml\#reprintsus

Neurol Neuroimmunol Neuroinflamm is an official journal of the American Academy of Neurology.

Published since April 2014, it is an open-access, online-only, continuous publication journal. Copyright

Copyright $\odot 2020$ The Author(s). Published by Wolters Kluwer Health, Inc. on behalf of the American

Academy of Neurology.. All rights reserved. Online ISSN: 2332-7812.

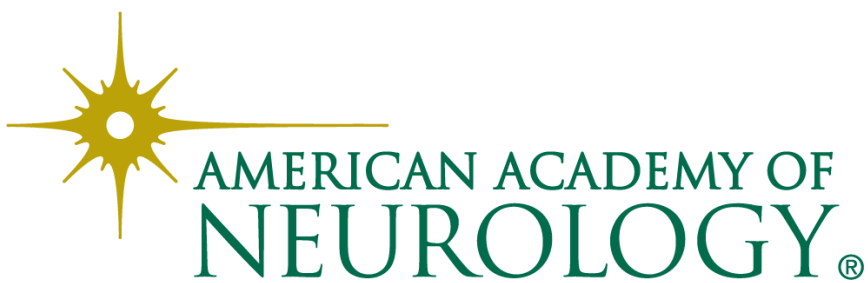

